\title{
Isolamento de fagócitos viáveis do leite de búfalas (Bubalus bubalis) hígidas, sem elicitação, criadas no estado de São Paulo
}

\section{Isolation of viable phagocytes from healthy buffaloes milk (Bubalus bubalis), without elicitation, bred in Sao Paulo state}

\author{
Alice Maria Melville Paiva Della Libera, ${ }^{*}$ Eduardo Harry Birgel, ${ }^{* *}$ Ênio Mori, ${ }^{* * *}$ Sandra Satiko Kitamura, ${ }^{* * * *}$ \\ Regina Mieko Sakata Mirandola ${ }^{, * * *}$ Wanderley Pereira de Araujo*****
}

\begin{abstract}
Resumo
A obtenção de células viáveis do leite em quantidade adequada tem sido considerada limitante para a avaliação das funções celulares, sem elicitação prévia e na ausência de inflamação. O presente estudo teve por objetivo padronizar o volume e descrever o processamento das amostras para a recuperação de $2 \times 10^{6}$ células viáveis $/ \mathrm{ml}$ em suspensão, a partir de leite de búfalas hígidas, sem elicitação, criadas no estado de São Paulo. Para tal, foram colhidas 114 amostras de leite de búfalas, negativas no CMT e ao isolamento bacteriológico, compondo-se três grupos com amostras constituídas de diferentes volumes $(100 \mathrm{a} 125 \mathrm{ml} ; 500 \mathrm{ml}$ e com $750 \mathrm{ml})$ de leite. As amostras foram submetidas à contagem de células somáticas e foram realizados os cálculos dos números e percentuais de células viáveis. Empregando-se esse procedimento para isolamento das células viáveis em quantidade e qualidade adequadas, concluiu-se que, em face da pequena concentração de células do leite de búfalas hígidas, foram necessários maiores volumes da amostra, fato que aumentou o tempo de processamento e manipulação das mesmas, comprometendo a viabilidade celular e conseqüentemente as aplicações experimentais futuras. $\mathrm{O}$ volume de $500 \mathrm{ml}$ de leite foi considerado o mais eficiente para a recuperação de células em quantidade e qualidade adequadas para ensaios in vitro.
\end{abstract}

Palavras-chave: fagócitos, viabilidade celular, leite, búfalos.

\begin{abstract}
The obtainment of viable cells from milk in adequate quantity has been considered a limiting factor for evaluation of cells functions, without previous elicitation and in absence of inflammation. The aim of the present work was to standardize volume and describe the samples processing for recover of $2 \times 10^{6}$ viable cells $/ \mathrm{ml}$ of healthy buffaloes milk, without elicitation, of animals bred in Sao Paulo state. For this purpose, 114 milk samples from mammary quarts of buffaloes negative for CMT and also for bacteriological isolation were obtained, building three samples groups with different milk volumes (100 - $125 \mathrm{ml} ; 500$ $\mathrm{ml}$ and $750 \mathrm{ml}$ ). The samples were analyzed for somatic cells count and viability. Using this experimental model for isolation of viable cells in adequate quantity and quality, we concluded that because of low cells concentration of healthy buffaloes milk, more volumes of samples were necessary. Therefore, this fact raised processing time and manipulation of samples. Low cellular viability may cause problems in downstream applications. The $500 \mathrm{ml}$ of volume milk was considered more efficient for recover of cells in adequate quantity and quality.
\end{abstract}

Keywords: phagocytes, cellular viability, milk, buffaloes.

\section{Introdução}

Com a evolução da imunologia clínica, protocolos para avaliações das funções celulares in vitro muito têm contribuído no estudo das alterações da glândula mamária (Dhakal et al, 1991; Silva e Kariyawasam, 1996). Para tanto, é necessário que as células sejam obtidas em quantidade (Concha e Holmberg, 1990) e qualidade (Piccinini et al., 1990) adequadas e passíveis de serem preservadas em condições próximas às condições in vivo (Schalm et al., 1971, Desiderio e Campbell, 1980; Nonnecke e Kehrli, 1985) e portanto sem elicitação. As limitações técnicas se acentuam em amostras

\footnotetext{
* Professor doutor, Dep. de Clínica Médica, Faculdade de Medicina Veterinária e Zootecnia da Universidade de São Paulo (FMVZ USP). Rua Orlando Marques Paiva, 87, CEP 05588-000, Cidade Universitária, SP. E-mail: dellalibera@fmvz.usp.br.

** Professor Titular, Departamento de Clínica Médica (FMVZ-USP).

*** Doutorando do Departamento de Clínica Médica, (FMVZ-USP), Clínica Médica da UNIABC.

**** Doutorando do Departamento de Clínica Médica, (FMVZ-USP), Clínica Médica da UNIP.

***** Farmacêutica Departamento de Clínica Médica, (FMVZ-USP).

****** Professor Associado, Departamento de Clínica Médica, (FMVZ-USP).
} 
de secreções lácteas com pequena concentração de células, provenientes de glândulas mamárias não acometidas por qualquer forma de mamite (Sandgren et al., 1991).

A viabilidade celular significa o percentual das células disponíveis para manifestação de suas atividades ou, em outras palavras, a população celular funcional (Dhakal et al., 1991). Esse índice foi valorizado por Piccinini et al. (1990) que descreveram maior viabilidade em amostras de leite de vacas com mamite e consideraram a viabilidade como um "fator imunológico" que deveria ser considerado junto aos demais fatores de defesa da glândula mamária.

As raras pesquisas específicas sobre a função de células do leite de búfalas, além de avaliarem a contagem total de células, priorizaram estudos envolvendo neutrófilos após indução de aumento da celularidade, e deixaram claro que existem diferenças quantitativas e qualitativas na celularidade desses animais, quando comparados a bovinos (Silva e Silva, 1994; Kehrli e Harp, 2001).

O presente estudo teve por objetivo padronizar o volume e descrever o processamento das amostras para a recuperação de $2 \times 10^{6}$ células viáveis $/ \mathrm{ml}$ em suspensão, a partir de leite de búfalas hígidas, sem elicitação, criadas no estado de São Paulo.

\section{Material e métodos}

Foram colhidas 114 amostras de leite (constituídas de três alíquotas) de 29 búfalas da raça Murrah, cujos quartos mamários não apresentavam alterações ao exame físico da glândula mamária, além de ausência de grumos no leite, CMT e exame microbiológico negativos. A primeira alíquota destinava-se ao exame microbiológico e foi colhida assepticamente. A segunda alíquota foi colhida em frasco plástico contendo bronopol e encaminhada para a contagem de células somáticas (CCS) automática. ${ }^{1}$ A terceira alíquota foi colhida em diferentes volumes, em recipiente plástico com capacidade de $750 \mathrm{ml}$. Uma vez colhido, o leite dessa alíquota da amostra era imediatamente filtrado em gaze estéril e transferido para frasco de polipropileno contendo igual quantidade de

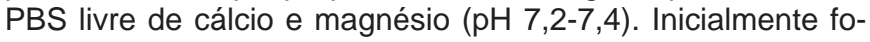
ram colhidas 42 amostras compostas de 100 a $125 \mathrm{ml}$ de leite e, posteriormente 60 amostras contendo $500 \mathrm{ml}$ de leite e 12 amostras contendo $750 \mathrm{ml}$ de leite. As amostras foram transportadas em recipientes isotérmicos contendo gelo picado e isoladas com papel toalha, impedindo o contato direto dos frascos com o gelo, e atenuando choques do transporte. A temperatura foi controlada a $4^{\circ} \mathrm{C}$ mantendo-se um termômetro digital cujo sensor foi fixado dentro de uma amostra controle, além de outro termômetro de mínima e de máxima dentro do isopor. A temperatura da amostra foi igualmente controlada durante todo o processamento, além de ter sido usado material exclusivamente plástico para impedir o comprometimento principalmente das células da série dos macrófagos (Jensen e Eberhart, 1981; Silva et al., 1996).

Várias forças reais de centrifugação (FRC) foram testadas nessa pesquisa no processamento das amostras da secreção láctea de búfala, fazendo-se sempre a avaliação citológica da fração sobrenadante, sendo selecionada a $\mathrm{FRC}=450 \mathrm{~g}$

\footnotetext{
1 Bentley 2000; Análises realizadas no Programa de Análise de Reba-
} nhos Leiteiros, Curitiba, PR. por 20 minutos, a $4^{\circ} \mathrm{C}$. Procedeu-se a primeira centrifugação

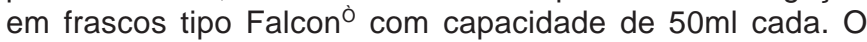
sobrenadante mais viscoso formado na porção superior dos frascos (tampão de gordura), foi retirado com o auxílio de uma espátula ou simplesmente teve seus bordos descolados da parede do frasco, para depois reverter o conteúdo do frasco uma única vez. Após desprezar totalmente a fração sobrenadante líquida, ainda com o frasco invertido, procedeu-se a limpeza dos lados internos com papel absorvente macio e, só então, revertia-se novamente o frasco. As células sedimentadas foram suavemente ressuspendidas com fracos jatos de PBS e todo material ressuspendido de uma mesma amostra centrifugada em vários frascos, foi colocado em outro frasco tipo Falcon ${ }^{\grave{~}}$ estéril e o volume de $50 \mathrm{ml}$ completado com PBS refrigerado. A suspensão com os sedimentos concentrados (pellet de células) do leite foi novamente centrifugada nas condições anteriormente descritas, desprezando-se o sobrenadante e ressupendendo-se o sedimento em $1 \mathrm{ml}$ de meio enriquecido (RPMI 1640; GIBCO® 3180004). Essa suspensão celular foi submetida à prova de exclusão de azul de tripan para quantificação de células viáveis (índice de viabilidade). A concentração de células viáveis correspondeu às células contadas em câmara para contagem de leucócitos, que não adquiriram coloração azul, não se impregnando com o corante. Para converter o número de células contadas no resultado final expresso em células $/ \mathrm{ml}$, esse foi multiplicado por $10^{5}$ e depois convertido para $10^{6}$, uma vez que para a maioria das avaliações in vitro seriam necessárias 2 × $10^{6}$ células $/ \mathrm{ml}$.

A viabilidade celular das amostras foi avaliada por análise de variância e as médias, comparadas pelo teste de Duncan. As CCS e a concentração de células viáveis foram analisadas pelo teste de Mann-Whitney (Sampaio, 1998), usando-se software estatístico SAS (2001) e Minitab (2000). Foram calculadas as freqüências de amostras adequadas (mínimo de 2 $\times 10^{6}$ células/ml) e quando necessário, calculou-se o coeficiente de correlação de Pearson entre as variáveis estudadas.

\section{Resultado e discussão}

A viabilidade celular média das 114 amostras de leite de búfalas hígidas foi de $62,1 \pm 19,3 \%$ e da CCS média foi de 14.000 células $/ \mathrm{ml}$. A proposta de triagem das amostras de no mínimo $2 \times 10^{6}$ células $/ \mathrm{ml}$, foi mais rígida do que a adotada por Silva e Silva (1994), pois a confiabilidade na execução de uma avaliação in vitro dependeria desta etapa (Sandgren et al., 1991).

A prova negativa do CMT utilizada como critério de seleção nesta investigação fez prever-se pequena magnitude de células presentes nas amostras, sem que se pudesse estimar o número de células viáveis, provavelmente com contagem menor do que 200.000 células viáveis/ml (Schalm et al.,1971), fato confirmado pela menor contagem encontrada neste ensaio.

Com base neste resultado, houve a necessidade de se utilizar volumes maiores de leite para obtenção de $2 \times 10^{6}$ células $/ \mathrm{ml}$. Nonnecke e Kehrli (1985) recomendaram aumentar a quantidade de PBS adicionado ao leite para favorecer a recuperação celular. Quanto ao PBS, observou-se que discretas oscilações do pH causaram perdas das amostras de leite

\footnotetext{
Falcon - Corning
} 
colhidas e que esse deveria ser mantido continuamente refrigerado e em continente isotérmico.

Quanto à viabilidade celular neste estudo, encontraram-se valores semelhantes nas amostras dos grupos com 100 a 125 e $500 \mathrm{ml}$ e maiores em relação ao grupo de $750 \mathrm{ml}(p<0,04)$. Por outro lado, a percentagem de amostras com concentração mínima de $2 \times 10^{6}$ células $/ \mathrm{ml}$, foi aumentando gradativamente até atingir $100 \%$ de aproveitamento, quando se utilizou $750 \mathrm{ml}$ de leite, ou seja, a percentagem de amostras com concentração mínima de $2 \times 10^{6}$ células $/ \mathrm{ml}$ aumentou enquanto a viabilidade celular diminuiu significativamente. Em relação à concentração celular, houve uma diferença significativa $(p<0,01)$, onde com os volumes de 100 a $125 \mathrm{ml}$ obteve-se $1,0 \times 10^{6}$ células $/ \mathrm{ml}$, aumentando para $2,1 \times 10^{6} \mathrm{e}$ $3,8 \times 10^{6}$ células $/ \mathrm{ml}$ com volumes de 500 e $750 \mathrm{ml}$ de leite, respectivamente (Tabela 1 ).

Os valores da viabilidade encontrados foram iguais aos descritos por Nonnecke e Kehrli (1985), apesar desses autores

Tabela 1 - Viabilidade celular, freqüência de obtenção de suspensão com 2 x 106 células viáveis e medianas do número de células isoladas por ml de leite.

\begin{tabular}{c|cccc}
\hline $\begin{array}{c}\text { Volume de leite } \\
(\mathbf{m l})\end{array}$ & № & $\begin{array}{c}\text { Viabilidade } \\
\text { celular } \\
(\%)\end{array}$ & $\begin{array}{c}\text { Amostras } \\
\text { adequadas }(\%)\end{array}$ & $\begin{array}{c}\text { Células viáveis } \\
\left(\mathbf{x ~ 1 0 ^ { 6 }} \text { células } / \mathbf{m l}\right)\end{array}$ \\
\hline $100-125$ & 42 & $65,3 \pm 21,4^{\text {a\# }}$ & 35,7 & $1,0^{\mathrm{c} \# \#}$ \\
500 & 60 & $61,4 \pm 17,0^{\mathrm{a}}$ & 56,7 & $2,1^{\mathrm{b}}$ \\
750 & 12 & $46,1 \pm 17,2^{\mathrm{b}}$ & 100 & $3,8^{\mathrm{a}}$ \\
\hline
\end{tabular}

Letras distintas na mesma coluna indica diferença estatística entre si (\# $p<0,04$; \#\# $p<0,01$ ). volumes de leite.

Deve-se ressaltar que entre a colheita e a avaliação da viabilidade decorreram cerca de quatro horas, utilizadas para o transporte da propriedade ao laboratório, onde a amostra foi centrifugada durante 20 minutos por duas vezes. A suspensão celular deve ser obtida o mais rápido possível para obtenção de maior concentração de células somáticas viáveis e, considerando-se que o processamento inicial consumiria muito tempo, a viabilidade poderia ser comprometida. Poucos relatos referiram essa tolerância, mas é muito provável que o tempo de processamento da amostra possa interfir no resultado final, fator minimizado se houvesse uma centrífuga que acondicionasse frascos que pudessem conter maiores

Nonnecke e Kehrli (1985) utilizaram amostras de maiores volumes, porém as etapas não foram adequadamente descritas pelos autores. Apesar disso, a correlação positiva entre o volume da amostra e a concentração celular foi baixa porém significativa $(r=0,24 ; p<0,009)$, sugerindo que na dependência da amostra, as células poderiam ser mais susceptíveis as perdas durante o processamento ou então mais frágeis e com menor vitalidade.

As amostras de leite foram colhidas de búfalas que não apresentavam alterações da glândula mamária, principalmente processos inflamatórios. Nestas condições, as células do leite não estariam sendo mobilizadas intensamente da circulação sangüínea para a mama, como nos casos de mamite. Nos casos de inflamação de origem bacteriana, as células mobilizadas com o objetivo de controlar o processo teriam maior atividade, porém menos resistentes

terem utilizado leite bovino mantido em temperatura ambiente, porém os valores obtidos no presente estudo foram discordantes de Concha e Holmberg (1990), por terem sido evidentemente menores. Esses últimos pesquisadores obtiveram 3 x $10^{6}$ células $/ \mathrm{ml}$ com até $90 \%$ de viabilidade com amostras de $400 \mathrm{ml}$ de leite bovino, sem elicitação, utilizando a primeira centrifugação a $800 \mathrm{~g}$ por 20 minutos e diluição de 1:2 PBS.

Entre os valores obtidos para a CCS e a concentração de células viáveis, pôde-se observar uma correlação positiva $(r=0,59 ; p<0,0001)$, indicando que quanto maior o número de células somáticas na amostra de leite, maior a concentração de células viáveis (Figura 1), como Kehrli e Harp (2001) evidenciaram em amostras de leite bovino.

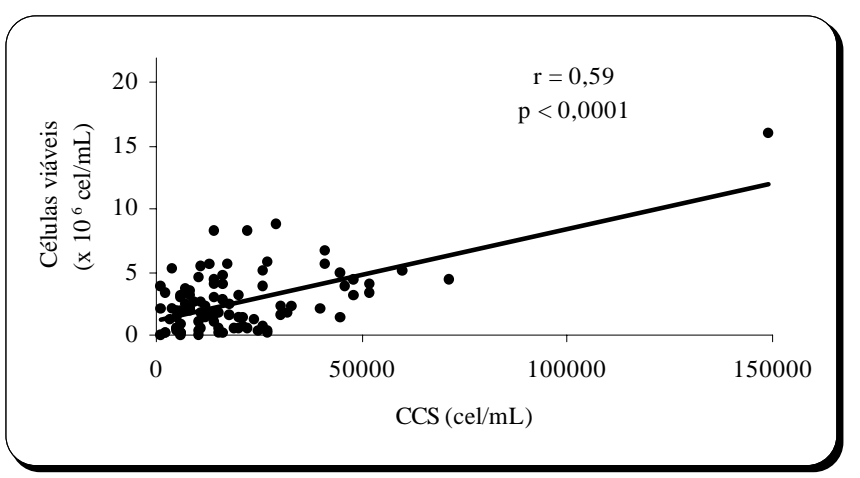

Figura 1 - Correlação entre a CCS (células/ml) e a concentração de células viáveis $\left(x 10^{6}\right.$ células $\left./ \mathrm{ml}\right)$ do leite. ao processamento de concentração. Os resultados obtidos foram concordantes com Piccinini et al. (1990), Dhakal et al. (1991) que também referiram maior celularidade e viabilidade em grupos acometidos por mamite, independentemente da fase de ordenha em que as amostras foram colhidas.

A necessidade de se utilizar um maior volume de leite para obtenção de células em quantidade e qualidade satisfatórias para a execução de provas de avaliação funcional, poderia limitar a sua realização em búfalas, que na média, produzem menos leite que bovinos com aptidão leiteira. Nonnecke e Kehrli (1985) ao desenvolverem pesquisas para avaliarem a atividade linfocitária do leite de bovinos, colheram 8 litros justificados pela pequena população em animais sadios. Mesmo assim, concluíram que poderiam recuperar células do leite, sem elicitação prévia, e portanto em condições mais próximas às fisiológicas como proposto por Desiderio e Campbell (1980).

\section{Conclusão}

A concentração celular é pequena no leite de búfalas hígidas, verificando-se que o aumento do volume das amostras de leite aumentou o tempo de processamento diminuindo a viabilidade celular apesar da obtenção de maior concentração celular.

O volume de $500 \mathrm{ml}$ de leite foi o mais adequado para a recuperação de $2 \times 10^{6}$ células viáveis $/ \mathrm{ml}$, empregando a metodologia aqui descrita. 


\section{Referências}

CONCHA, C.; HOLMBERG, O. Ability of bovine mammary macrophages to enhance proliferation of autologous blood and mammary secretion lymphocytes. Journal of Dairy Research, v. 57, p. 7-16, 1990.

DESIDERIO, J. V.; CAMPBELL, S. G. Bovine mammary gland macrophage: Isolation, morphologic features, and cytophilic immunoglobulins. American Journal Veterinary Research, v. 41, n. 10, p. 1595-1599, 1980.

DHAKAL, J. P.; KAPUR, M. P.; BHARDWAJ, R. M. Diagnosis of subclinical mastitis in buffaloes using somatic and viable cell counts. Indian Journal of Animal Health, v. 44, n. 9, p. 585-586, 1991.

JENSEN, D. L; EBERHART, R. J. Total and differential cell counts in secretions of the nonlactating bovine mammary gland. American Journal Veterinary Research, v. 42, p. 743-747, 1981.

KEHRLI, M. E.; HARP, J. A. Immunity in the mammary gland. Veterinary Clinics of North America: Food animal practice, v. 17, n. 3, p. 495-515, 2001.

PICCININI, R.; BRONZO, V.; MORONI, P.; LUZZAGO, C.; ZECCONI, A. Study on the relationship between milk immune factors and Staphylococcus aureus intramammary infections in dairy cows. Journal of Dairy Research, v. 66, p. 501-510, 1999.
NONNECKE, B. J.; KEHRLI, M. E. Isolation of mononuclear cells from bovine milk by continuous-flow and density gradient centrifugation: response of cells to mitogens. American Journal of Veterinary Research, v. 46, n. 6, p. 1259-1262, 1985.

SANDGREN, C. H.; NORDLING, K.; BJÖRK, I. Isolation and phagocytic properties of neutrophils and other phagocytes from nonmastitic bovine milk. Journal of Dairy Science, v. 74, p. 2965-2975, 1991.

SCHALM, O. W.; CARROL, E. J.; JAIN, N. C. Bovine mastitis. Philadelphia: Lea e Febiger, 1971.

SILVA, I. D.; SILVA, K. F. S. T. Total and differential cell counts in buffalo (Bubalus bubalis) milk. Buffalo Journal, v. 10, n. 2, p. 133-137, 1994.

SILVA, I; KARIYAWASAM, S. Postphagocytic bactericidal activity of buffalo (Bubalus bubalis) neutrophils against mastitis causing bacteria. Journal of the National Science Council of Sri Lanka, v. 24, n. 2, p. 71 80, 1996.

MINITAB - The Student Edition of MINITAB Statistical software adapted for education - 13.0 Release. User's Manual. New York: Addison Wesley, 2000.

SAMPAIO, I. B. M. Estatística aplicada à experimentação animal. Belo Horizonte: Universidade Federal de Minas Gerais, 1998.

SAS INSTITUTE. SAS user's guide:statistics. Cary: SAS Institute, 2001. 